\title{
Pengujian Batu Apung Sebagai Filler Pada Campuran HRS -WC
}

\author{
Sri Yanti ${ }^{{ }^{*},}$ Rosiana ${ }^{* 2}$, Alpius ${ }^{*}$, Desy Sandy ${ }^{* 4}$ \\ *1,2 Mahasiswa Prodi Teknik Sipil, Universitas Kristen Indonesia Paulus, Makassar, Indonesia \\ yantysri@yahoo.com rosiioctaviaa@yahoo.com \\ *3,4 Dosen Prodi Teknik Sipil, Universitas Kristen Indonesia Paulus, Makassar, Indonesia \\ alpiusnini@yahoo.com, sandy.mylife@yahoo.co.id
}

\begin{abstract}
ABSTRAK
Penelitian ini dimaksudkan untuk merancang komposisi dan menganalisis karakteristik marshall dan indeks kekuatan sisa campuran Lataston HRS-WC gradasi senjang dan semi senjang yang memanfaatkan batu apung dari Provinsi Maluku Utara, Pulau Ternate sebagai pengganti filler. Metodologi dalam penelitian ini adalah melakukan serangkaian pengujian karakteristik berupa agregat kasar, halus dan filler lalu merancang komposisi campuran kemudian pembuatan benda uji berupa campuran Lataston HRS-WC bergradasi senjang dan semi senjang serta pengujian Marshall untuk mendapatkan karakteristik campuran dan pengujian Marshall Immertion untuk mendapatkan Indeks Perendaman (IP) / Indeks Kekuatan Sisa (IKS) / Durabilitas campuran yang berkadar filler optimum. Hasil penelitian menunjukkan bahwa karakteristik abu batu apung memenuhi spesifikasi sebagai bahan pengganti filler pada campuran Lataston HRS-WC gradasi senjang dan semi senjang. Melalui uji Marshall diperoleh karakteristik campuran Lataston HRS-WC bergradasi senjang dan semi senjang dengan kadar aspal 6,75\%. Hasil pengujian Marshall Immertion campuran Lataston HRS-WC bergradasi senjang dan semi senjang dengan kadar filler optimum 100\% mendapatkan Indeks Perendaman (IP) / Indeks Kekuatan Sisa (IKS) / Durabilitas campuran sebesar 95,73\% dan $96,66 \%$ yang artinya campuran tersebut tahan terhadap suhu, lamanya terendam air.
\end{abstract}

Kata Kunci : Karakteristik, HRS-WC Marshall, filler batu apung

\begin{abstract}
This research is intended to design the composition and analyze the characteristics of Marshall and strength index of the remaining mixture of Lataston HRS-WC gradation and semi-gap gradation which uses pumice from North Maluku Province, Ternate Island as a substitute for filler. The methodology in this research is to conduct a series of characteristics testing in the form of coarse, fine aggregate and filler and then design the composition of the mixture then manufacture test specimens in the form of a Lataston HRS-WC graded gap and semi-gap length and Marshall test to obtain the mixture characteristics and Marshall Immertion test to obtain an Immersion Index (IP) / Residual Strength Index (IKS) / Durability of mixtures containing optimum filler content. The results showed that the characteristics of pumice ash meet the specifications as a substitute for filler in the Lataston HRS-WC mixture of gradation and semi-gap gradation. Through the Marshall test, the characteristics of the Lataston HRS-WC mixture with a graded gap and semi-gap with asphalt content of $6.75 \%$, meet the requirements issued by the Directorate General of Highways of the Republic of Indonesia Ministry of Public Works, General Specifications 2010 Division 6 revision 3. Marshall Immertion test results mixture of Lataston HRS-WC graded gaps and semi-gaps with optimum filler content $100 \%$ get an Soaking Index (IP) / Residual Strength Index (IKS) / Durability of a mixture of $95.73 \%$ and $96.66 \%$ which means the mixture is resistant to temperature, time immersed in water.
\end{abstract}

Keywords: Characteristics, Marshall HRS-WC, pumice filler

\section{PENDAHULUAN}

Potensi sumber daya alam di bidang pertambangan cukup melimpah di Indonesia. Salah satunya adalah potensi ketersedian batu apung. Persebaran batu apung di Indonesia meliputi Pulau Sumatera bagian tengah, Provinsi Sumatera Selatan, Provinsi Lampung, Provinsi Jawa Barat, Provinsi Nusa Tenggara Barat, Provinsi Sulawesi Tengah, dan Pulau Ternate Provinsi Maluku Utara. Dilihat dari banyaknya batu apung yang ada di Indonesia sangat disayangkan apabila tidak dimanfaatkan secara baik.

Batu apung yang terdapat di Pulau Ternate adalah salah satu bahan lokal yang jumlahnya masih banyak sehingga masyarakat setempat sering menggunakannya untuk terapi kesehatan, penghias interior rumah, isolator temperatur tinggi, dan bahan bangunan. 
Salah satu campuran yang paling sering digunakan di Indonesia yang beriklim tropis yakni Hot Rolled Sheet (HRS). Karena mempunyai kelenturan yang tinggi, tahan terhadap kelelehan. HRS atau Lapisan Tipis Aspal Beton (Lataston) campuran bergradasi senjang dan semi senjang yang mutunya ditentukan oleh komposisi campuran antara aspal, agregat kasar, agregat halus dan filler yang bertujuan untuk mengurangi rongga/pori pada lapisan permukaan jalan [1].

Material yang umum digunakan sebagai filler pada penyusunan campuran beraspal adalah semen, kapur, dan abu terbang dimana persediannya terbatas serta relatif mahal. Oleh karena itu perlu ditemukan alternatif yang murah untuk mengganti filler yang selama ini banyak dipakai sebagai bahan campuran beton aspal. Salah satu alternatifnya adalah dengan pemanfaatan potensi daerah setempat. Pemanfaatan tersebut antara lain dengan menggunakan material dari batu apung yang dihaluskan menjadi abu. Sehingga dalam hal ini penulis mengadakan penelitian tehadap pemanfaatan batu apung yang terdapat di Pulau Ternate untuk mengetahui apakah batu apung pada daerah tersebut bisa dipakai sebagai bahan filler dalam campuran lataston.

Tujuan penelitian adalah untuk mengetahui karakteristik berat jenis filler batu apung; untuk mengetahui komposisi campuran Lataston HRS-WC yang menggunakan batu apung sebagai filler; dan mengetahui karakteristik marshall dan indeks kekuatan sisa campuran Lataston HRS-WC yang menggunakan batu apung sebagai filler .

\section{Penelitian Terdahulu}

Kinerja campuran HRS WC dengan filler abu ampas debu diperoleh nilai berat jenis agregat $2,54 \mathrm{~g} / \mathrm{cm}^{3}$, berat jenis SSD $2,57 \mathrm{~g} / \mathrm{cm} 3$, penyerapan $1,2 \%$, abrasi $34,8 \%$, berat jenis spesifik nilai agregat halus $2,5 \mathrm{~g} / \mathrm{cm}^{3}$, berat jenis SSD $2,55 \mathrm{~g} / \mathrm{cm}^{3}$, penyerapan $1,63 \%$, nilai kadar aspal optimum 7,2\%, uji Marshall MQ 319,22 kg/mm, VIM 5,31\%, VMA 18,67\%, dan VFB $72,03 \%$ [2].

Pengujian untuk campuran HRS menggunakan material piropilit sebagai filler yang tahan hujan asam menghasilkan polusi udara yang terjadi di Kota Surabaya tergolong aman dan tidak berpengaruh terhadap nilai stabilitas dan durabilitas dari campuran HRS [3].
Pengaruh penggunaan Pasir Carita sebagai campuran agregat halus pada lapis permukaan aspal beton terhadap parameter Marshall dengan komposisi 50\% Pasir Carita dan 50\% non Pasir Carita menghasilkan nilai stabilitas, kelelehan, $M Q$, VMA, VFB, dan VIM pada perkerasan AC-WC yang memenuhi persyaratan [4].

Studi penggunaan serbuk bata merah sebagai filler pada perkerasan HRS-WC dengan proporsi campuran pada HRS - WC 34\% (agregat kasar), $56 \%$ (Agregat Halus), 10\% (Filler). Dengan hasil penggunaan filler serbuk bata merah yang memenuhi standar Dinas Pekerjaan Umum Bina Marga adalah pada kadar aspal 6,5\% jadi nilai kadar aspal optimum (KAO) adalah 6,5\% [5].

Pengaruh kadar Zeolite sebagai filler terhadap campuran aspal beton yaitu variasi $4 \%$ filler abu batu : $6 \%$ filler zeolite, dengan kadar aspal 6\%, yaitu nilai density sebesar 2,321 $\mathrm{gr} / \mathrm{ml}$, nilai VFWA sebesar $74,57 \%$, nilai VITM sebesar $4,34 \%$, nilai stabilitas sebesar $1297,676 \mathrm{~kg}$, nilai flow sebesar $4 \mathrm{~mm}$, dan nilai QM sebesar $342,419 \mathrm{~kg} / \mathrm{mm}$. Pada variasi ini didapatkan nilai kadar aspal optimum sebesar 5,83\% [6].

Pemanfaatan abu Bagasse sebagai filler terhadap nilai Marshall Test pada campuran Asphalt Treated Base menghasilkan kadar Abu Bagasse optimum dengan penambahan variasi kadar Abu Bagasse yang berbeda akan menghasilkan kadar Abu Bagasse optimum untuk Marshall Quotient sebesar 46\% dengan nilai Marshall Quotient sebesar 5,06 $\mathrm{KN} / \mathrm{mm}$ [7] .

\section{METODOLOGI PENELITIAN}

Jenis penelitian ini adalah eksperimental yaitu serangkaian tahapan pengujian di Laboratorium Jalan dan aspal UKI Paulus Makassar dengan menguji karakteristik filler batu apung, merancang campuran dan menguji karakteristik campuran. Filler yang digunakan adalah batu apung yang diperoleh dari Laboratorium Bahan dan Beton UKI Paulus Makassar yang sebelumnya digunakan dalam penelitian mahasiswa. Proses pengolahan batu apung yaitu dimulai dengan pembersihan batu apung, pengeringan batu apung, penghalusan batu apung melalui ditumbuk secara manual dengan menggunakan palu besi, penyaringan batu apung dengan menggunakan saringan No.200, kemudian dihasilkan abu batu apung yang siap dijadikan filler. 


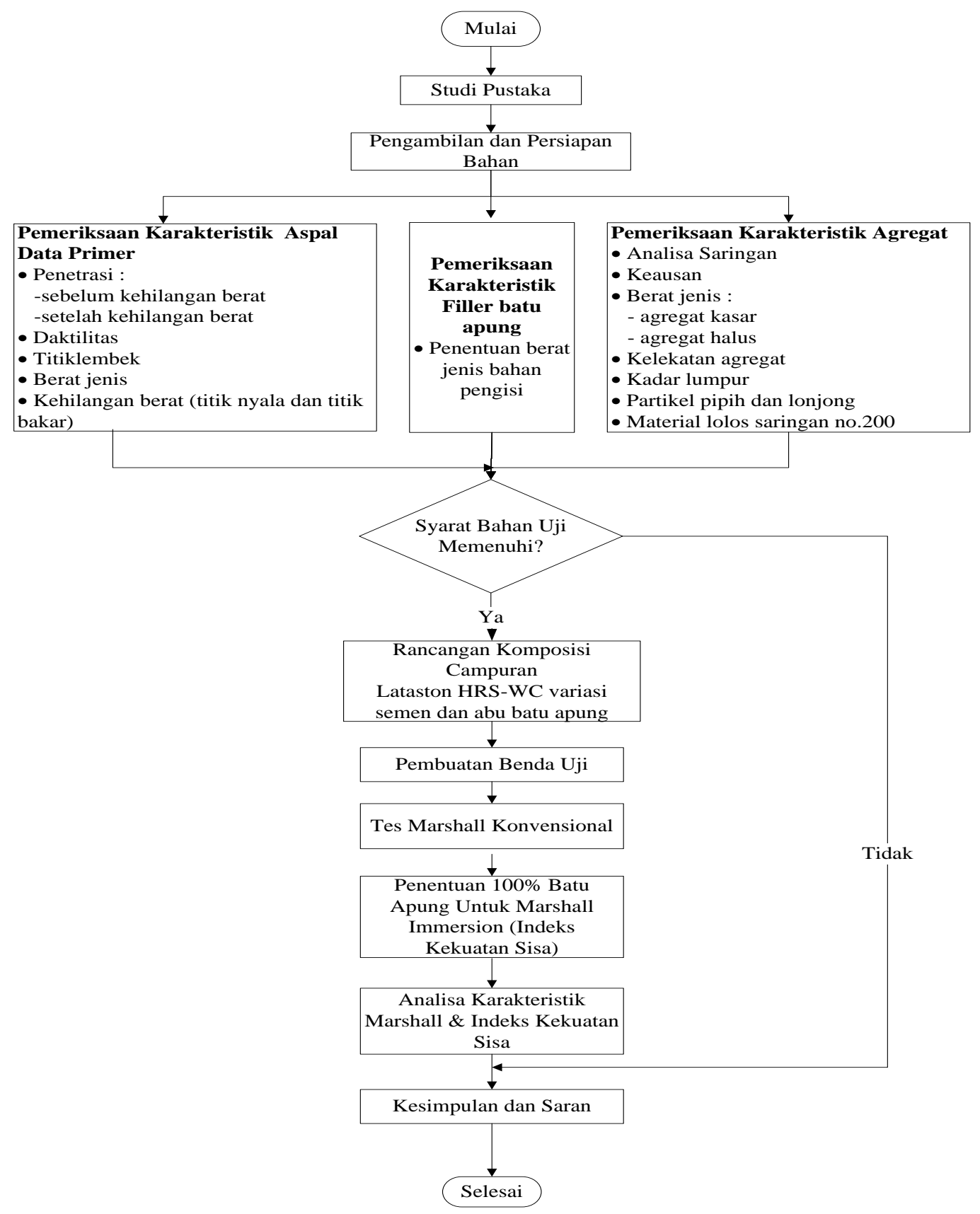

Secara keseluruhan terdapat dua variasi campuran yang dipilih dalam penelitian yaitu : tipe $A$ adalah campuran AC-WC dengan kadar pipih dan lonjong lebih besar dari standar (> 25\%) dengan jumlah sampel 15 buah dan tipe B adalah campuran AC-WC dengan kadar pipih dan lonjong 0\% (15 sampel).

Pengujian Marshall adalah untuk menentukan Kadar Aspal Optimum, yaitu kadar aspal dimana campuran yang dihasilkan memiliki sifat-sifat yang terbaik berdasarkan pengujian sifat-sifat volumetrik (kepadatan, VIM, VMA dan VFA) dan karakteristik Marshall (stabilitas, kelelehan dan Marshall Quotient) [1].

\section{HASIL DAN PEMBAHASAN}

\section{Berat Jenis dan Penyerapan Agregat Kasar}

Berat jenis dan penyerapan agregat kasar yang menggunakan dua sampel diperoleh nilai rata-rata untuk Berat Jenis Bulk adalah 2,67 \%, berat jenis SSD adalah $2,70 \%$, berat jenis semu adalah $2,75 \%$, dan penyerapan air adalah $1,05 \%$. Semua hasil pengujian memenuhi standar Bina Marga yaitu untuk Berat Jenis Bulk adalah minimal 2,5\%, Berat Jenis SSD adalah minimal 2,5\%, Berat Jenis Semua adalah minimal 2,5\%, dan Penyerapan Air maksimal $3 \%$.

2. Berat Jenis dan Penyerapan Agregat Halus 
Berat jenis dan penyerapan agregat halus yang menggunakan dua sampel diperoleh nilai rata-rata untuk Berat Jenis Bulk adalah 2,54\%, berat jenis SSD adalah 2,59\%, berat jenis semu adalah 2,66 \%, dan penyerapan air adalah 1,73\%. Semua hasil pengujian memenuhi standar Bina Marga yaitu untuk Berat Jenis Bulk adalah minimal 2,5\%, Berat Jenis SSD adalah minimal 2,5\%, Berat Jenis Semu adalah minimal 2,5\%, dan Penyerapan Air maksimal 3\%.

\section{Analisa Saringan}

Hasil pengujian analisa saringan untuk Lataston HRS-WC gradasi senjang dan semi senjang dapat disimpulkan bahwa untuk gradasi agregat dapat digunakan untuk campuran Lataston HRS-WC gradasi senjang dan semi senjang.

\section{Keausan dengan Alat Abrasi Los Angeles}

Hasil pengujian keausan agregat dengan menggunakan Alat Abrasi Los Angeles diperoleh nilai ketahanan agregat kasar terhadap keausan dari Fraksi A adalah 15,72\%, Fraksi B adalah 17,18\%, Fraksi C adalah 20,16\%, Fraksi D adalah 28,04\%. Semuanya memenuhi standar Bina Marga yaitu maksimum 40\%. Dari hasil pengujian keausan agregat, dapat diketahui bahwa agregat yang digunakan sebagai bahan lapisan permukaan jalan dapat tahan terhadap keausan akibat gesekan antara agregat dengan agregat atau agregat dengan roda kendaraan.

\section{Kelekatan Agregat terhadap Aspal}

Nilai kelekatan ditentukan dari luas permukaan sampel yang terselimuti aspal (kurang dari 95\% atau lebih dari 95\%). Dari pengamatan ini dapat diketahui bahwa aspal dapat melekat dengan baik pada agregat dengan nilai kelekatan $>95 \%$.

\section{Kadar Lumpur}

Hasil pengujian kadar lumpur dengan menggunakan 2 (dua) sampel diperoleh hasil rata-rata untuk nilai Sand Equivalent (SE) adalah 97,86\% dan kadar lumpur adalah 2,14\%. Keduanya memenuhi standar Bina Marga yaitu minimal 50\% untuk Sand Equivalent dan maksimal 5\% untuk kadar lumpur.

\section{Indeks Kepipihan dan Kelonjongan}

Hasil pengujian indeks kepipihan dan kelonjongan agregat kasar diperoleh indeks kepipihan yaitu $3,65 \%, \quad 2,45 \%, \quad 1,50 \%, \quad 1,10 \%$. Dan indeks kelonjongan yaitu $2,70 \%, 1,19 \%, 1,34 \%, 1,83 \%$.

\section{Material Lolos Saringan No. 200}

Hasil pengujian material lolos saringan No.200 diperoleh hasil memenuhi standar Bina Marga yaitu maksimal 8\%. Dapat diketahui bahwa agregat tersebut bersih dari lempung dan lanau.

\section{Berat Jenis Filler}

Spesifikasi Bina Marga tidak mencantumkan nilai batasan untuk berat jenis filler. Filler yang digunakan adalah batu apung dari Ternate.

Hasil rata-rata untuk nilai penetrasi sebelum kehilangan berat adalah 68,8 dmm telah memenuhi standar Bina Marga yaitu minimal $60(0,1) \mathrm{mm}$ maksimum $79(0,1) \mathrm{mm}$ untuk nilai penetrasi aspal.

\section{Pemeriksaan Daktilitas (Kelenturan)}

Aspal hasil rata-rata untuk nilai daktilitas adalah 149 $\mathrm{cm}$, telah memenuhi standar Bina Marga yaitu minimal $100 \mathrm{~cm}$ untuk nilai daktilitas.

\section{Pemeriksaan Titik Lembek Aspal}

Hasil rata-rata untuk nilai titik lembek adalah $48^{\circ} \mathrm{C}$. telah memenuhi standar Bina Marga yaitu minimal $48^{\circ} \mathrm{C}$ dan maksimal $58^{\circ} \mathrm{C}$ untuk nilai titik lembek.

\section{Pengujian Titik Nyala dan Titik Bakar}

Dari hasil pengujian titik nyala dan titik bakar didapatkan nilai rata-rata 300 . Nilai ini masuk dalam syarat yang ditentukan dalan SNI $2433-2011$ yaitu Min 200.

\section{Pemeriksaan Berat Jenis Aspal}

Hasil rata-rata untuk nilai berat jenis aspal adalah 1,037 gram/cc, telah memenuhi standar Bina Marga yaitu minimal 1 gram/cc untuk nilai berat jenis aspal.

\section{Pemeriksaan Penurunan Berat Aspal}

Hasil rata-rata untuk nilai penurunan berat aspal adalah 0,142\%, telah memenuhi standar Bina Marga yaitu maksimal $0,8 \%$ untuk nilai penurunan berat aspal.

\section{Penetrasi Sesudah Kehilangan Berat}

Hasil rata-rata untuk nilai penetrasi sesudah kehilangan berat adalah 65,9 dmm, telah memenuhi standar Bina Marga yaitu minimal $60(0,1) \mathrm{mm}$ maksimum 79 90,1) mm untuk nilai penetrasi aspal.

\section{Data dan Analisis Campuran Beraspal}

Pada pemadatan standar Marhall dalam penelitian ini hanya menggunakan 2x75 tumbukan (lalu lintas berat). Hasil pengujian Marshall terhadap benda uji menggunakan pemadatan standar. 
Tabel 1. Hasil pengujian karakterisitk Marshall HRS WC gradasi senjang

\begin{tabular}{|c|c|c|c|c|c|c|c|}
\hline \multirow{2}{*}{$\begin{array}{c}\text { Kadar Filler Batu } \\
\text { Apung }\end{array}$} & PERSYARATAN & Min 4-6(\%) & Min 800 & Min 68 & Min 3 & Min 250 & Min 18 \\
\hline & Kadar Aspal (\%) & VIM & Stabilias & VFB & Flow & MQ & VMA \\
\hline $0 \%$ & 6,75 & 4,51 & 2012,65 & 75,84 & 4,00 & 503,16 & 18,68 \\
\hline $0 \%$ & 6,75 & 4,41 & 1975,72 & 76,28 & 4,45 & 443,98 & 18,59 \\
\hline $0 \%$ & 6,75 & 4,54 & 1901,86 & 75,74 & 4,60 & 413,45 & 18,70 \\
\hline $25 \%$ & 6,75 & 4,80 & 2215,76 & 74,35 & 3,95 & 560,95 & 18,70 \\
\hline $25 \%$ & 6,75 & 4,78 & 2345,02 & 74,43 & 3,82 & 613,88 & 18,69 \\
\hline $25 \%$ & 6,75 & 4,62 & 2326,55 & 75,11 & 3,80 & 612,25 & 18,55 \\
\hline $50 \%$ & 6,75 & 5,22 & 2548,13 & 72,82 & 3,21 & 793,81 & 19,20 \\
\hline $50 \%$ & 6,75 & 5,21 & 2529,66 & 72,86 & 3,10 & 816,02 & 19,19 \\
\hline $50 \%$ & 6,75 & 5,14 & 2455,81 & 73,13 & 3,00 & 818,60 & 19,14 \\
\hline $75 \%$ & 6,75 & 5,57 & 2068,05 & 71,08 & 3,20 & 646,26 & 19,28 \\
\hline $75 \%$ & 6,75 & 5,58 & 2104,98 & 71,07 & 3,50 & 601,42 & 19,28 \\
\hline $75 \%$ & 6,75 & 5,68 & 2012,65 & 70,66 & 3,30 & 609,89 & 19,37 \\
\hline $100 \%$ & 6,75 & 5,77 & 1846,47 & 70,55 & 3,80 & 485,91 & 19,59 \\
\hline $100 \%$ & 6,75 & 6,00 & 1791,08 & 69,69 & 3,62 & 494,77 & 19,79 \\
\hline $100 \%$ & 6,75 & 5,86 & 1772,61 & 70,21 & 3,58 & 495,14 & 19,67 \\
\hline
\end{tabular}

Tabel 2. Hasil pengujian karakterisitk Marshall Lataston HRS - WC gradasi semi senjang

\begin{tabular}{|c|c|c|c|c|c|c|c|}
\hline $\begin{array}{c}\text { Kadar Filler Batu } \\
\text { Apung }\end{array}$ & PERSYARATAN & Min 4-6(\%) & Min 800 & Min 68 & Min 3 & Min 250 & Min 18 \\
\hline & Kadar Aspal $(\%)$ & VIM & Stabilitas & VFB & Flow & MQ & VMA \\
\hline $0 \%$ & 6,75 & 4,16 & 2492,73 & 77,50 & 3,85 & 647,46 & 18,51 \\
\hline $0 \%$ & 6,75 & 4,20 & 2437,34 & 77,35 & 3,55 & 686,57 & 18,54 \\
\hline $0 \%$ & 6,75 & 4,29 & 2474,27 & 76,95 & 3,65 & 677,88 & 18,62 \\
\hline $25 \%$ & 6,75 & 4,56 & 2640,45 & 75,51 & 3,50 & 754,41 & 18,61 \\
\hline $25 \%$ & 6,75 & 4,65 & 2695,85 & 75,11 & 3,20 & 842,45 & 18,70 \\
\hline $25 \%$ & 6,75 & 4,52 & 2677,38 & 75,66 & 3,30 & 811,33 & 18,59 \\
\hline $50 \%$ & 6,75 & 4,86 & 2621,99 & 74,45 & 3,30 & 794,54 & 19,01 \\
\hline $50 \%$ & 6,75 & 4,86 & 2585,06 & 74,45 & 3,17 & 815,48 & 19,01 \\
\hline $50 \%$ & 6,75 & 4,82 & 2548,13 & 74,59 & 3,23 & 788,89 & 18,98 \\
\hline $75 \%$ & 6,75 & 5,06 & 2492,73 & 73,28 & 3,85 & 647,46 & 18,95 \\
\hline $75 \%$ & 6,75 & 5,04 & 2455,81 & 73,36 & 4,11 & 597,52 & 18,93 \\
\hline $75 \%$ & 6,75 & 5,14 & 2511,20 & 72,95 & 4,09 & 613,99 & 19,02 \\
\hline $100 \%$ & 6,75 & 5,57 & 2215,76 & 71,49 & 4,84 & 457,80 & 19,54 \\
\hline $100 \%$ & 6,75 & 5,53 & 2234,23 & 71,64 & 4,25 & 525,70 & 19,50 \\
\hline $100 \%$ & 6,75 & 5,56 & 2178,83 & 71,52 & 4,21 & 517,54 & 19,53 \\
\hline
\end{tabular}

\section{Analisis Terhadap VIM}

Berdasarkan Gambar 2 dapat disimpulkan bahwa semakin banyak filler batu apung yang digunakan maka nilai VIM semakin besar (bertambah) karena filler batu apung yang dihaluskan lebih halus dibandingkan semen memiliki volume yang lebih besar sehingga aspal akan menyelimuti permukaan filler dan sedikit yang mengisi rongga dalam campuran. Hubungan VIM Lataston HRS WC gradasi senjang dapat dilihat pada Gambar 2.

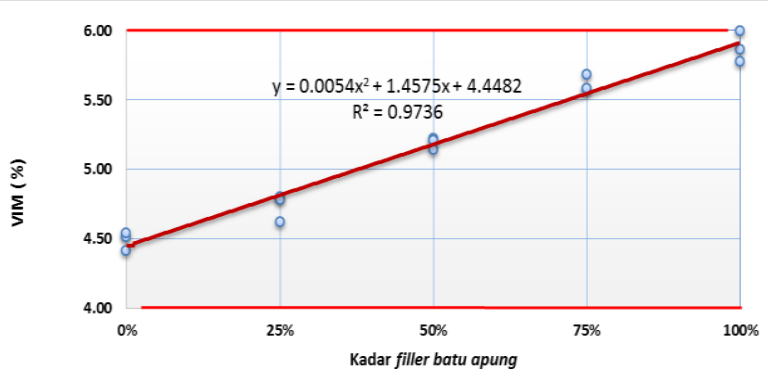

Gambar 2. Grafik hubungan VIM Lataston HRS WC gradasi senjang

Semakin banyak filler batu apung yang digunakan maka nilai VIM semakin besar (bertambah) karena filler batu apung yang dihaluskan lebih kasar dibandingkan semen sehingga rongga yang tidak terisi aspal (VIM) semakin bertambah. Hubungan VIM Lataston HRS WC gradasi semi senjang diperlihatkan pada Gambar 3.

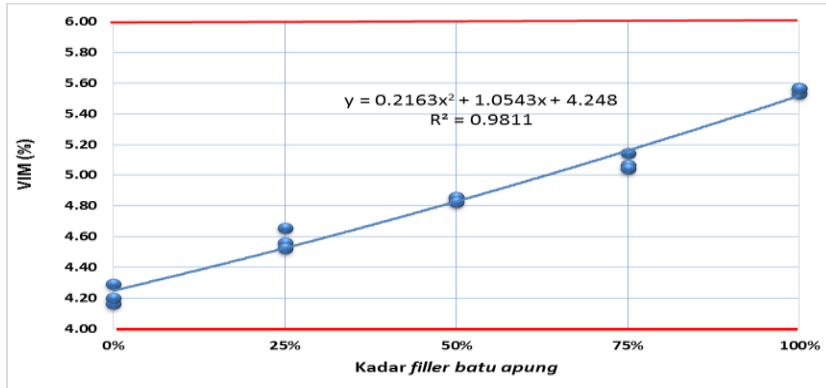

Gambar 3. Grafik hubungan VIM Lataston HRSWC gradasi semi senjang

\section{Analisis Terhadap Stabilitas}

Penggunaan filler batu apung pada proporsi 0\% $50 \%$ akan mencapai nilai stabilitas maksimum, tetapi pada penggunaan proporsi 75\% - $100 \%$ nilai stabilitas kembali menjadi menurun sehingga penggunaan filler batu apung yang terlalu tinggi menyebabkan nilai stabilitas menjadi rendah.

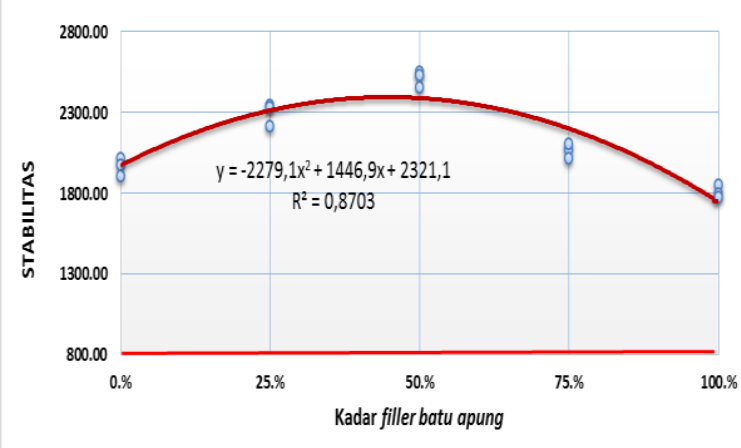

Gambar 4. Grafik hubungan stabilitas Lataston HRS-WC gradasi senjang

Penggunaan filler batu apung pada proporsi 0\% $25 \%$ akan mencapai nilai stabilitas maksimum, tetapi pada penggunaan proporsi 50\% - $100 \%$ nilai stabilitas kembali menjadi menurun sehingga penggunaan filler batu apung yang terlalu tinggi menyebabkan nilai stabilitas menjadi rendah. 


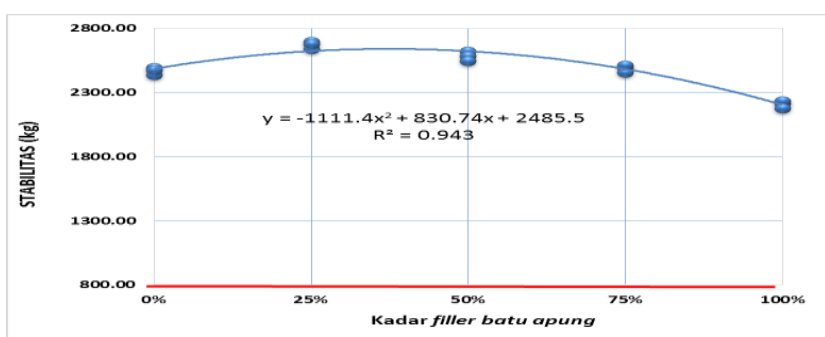

Gambar 5. Grafik hubungan stabilitas Lataston HRS-WC gradasi semi senjang

\section{Analisis Terhadap Flow}

Penggunaan batu apung sebagai filler akan menurunkan nilai flow. Hal ini dikarenakan rongga dalam campuran semakin meningkat sehingga membuat agregat tidak dapat terselimuti aspal dengan baik sehingga flow menurun. Hubungan flow Lataston HRS-WC gradasi senjang disajikan pada Gambar 6.

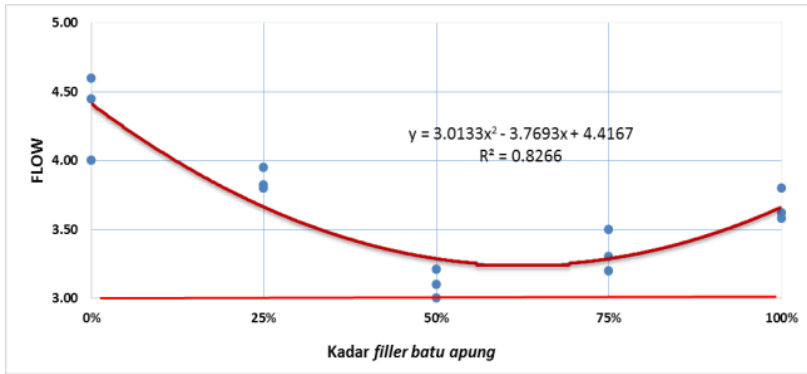

Gambar 6. Grafik hubungan flow Lataston HRSWC gradasi senjang

Penggunaan batu apung sebagai filler akan menyebabkan meningkatkan kelenturan/flow pada proporsi $50 \%$ - 100\% filler batu apung karena batu apung lebih lunak dibandingkan semen sehingga campuran menjadi lebih lunak/lentur. Hubungan flow lataston HRS WC gradasi seni senjang disajikan pada Gambar 7.

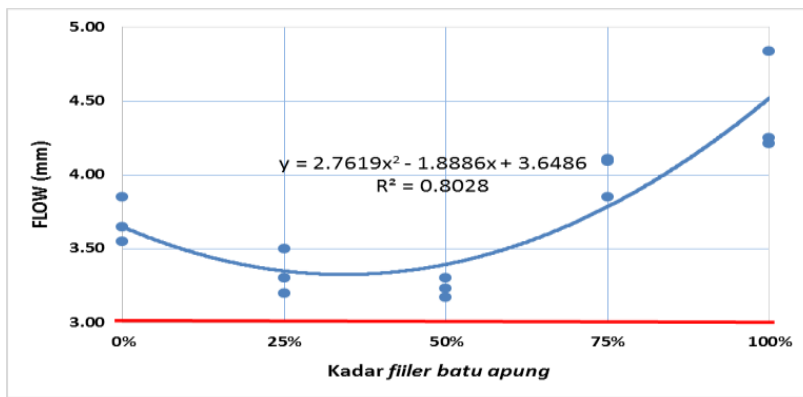

Gambar 7. Grafik Hubungan flow Lataston HRSWC gradasi semi senjang

\section{Analisis terhadap $M Q$ (Marshall Quotient)}

Dari hasil pengujian di laboratorium nilai $\mathrm{MQ}$ turun mengalami penurunan pada kadar variasi $100 \%$ yang menandakan berkurangnya volume filler batu apung maka nilai $\mathrm{MQ}$ akan turun pula dalam campuran. Seperti yang tergambar pada karakteristik marshall stabilitas dan flow, jika nilai stabilitas besar dan nilai flow kecil maka nilai MQnya akan besar, tetapi jika nilai stabilitas kecil dan flow besar, maka nilai MQnya akan menjadi kecil. Nilai $\mathrm{MQ}$ yang besar terdapat pada proporsi $\quad 50 \% \quad$ (MQ 809,48 $\mathrm{kg} / \mathrm{mm}$ ), memperlihatkan bahwa penggunaan filler batu apung dalam campuran nilai MQ bisa naik/besar.

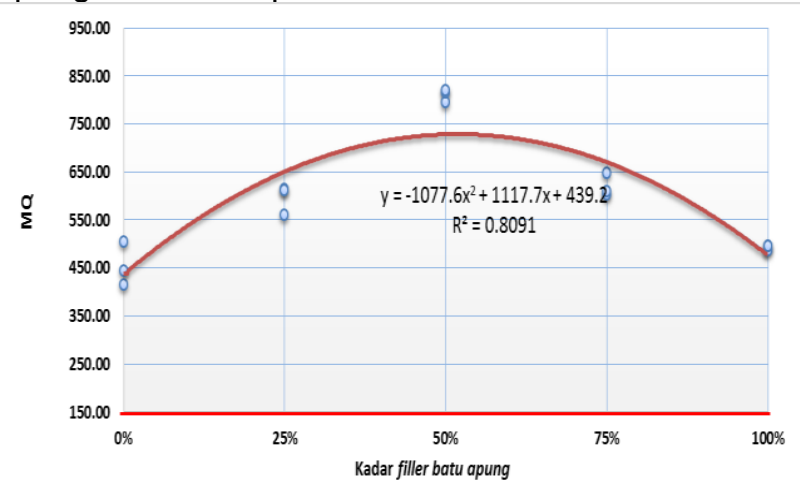

Gambar 8. Grafik hubungan Marshall Quotient (MQ) Lataston HRS-WC gradasi senjang

Dari hasil pengujian di laboratorium nilai $M Q$ mengalami penurunan hingga variasi kadar filler batu apung $100 \%$ yang menandakan bahwa bertambahnya kadar filler nilai $\mathrm{MQ}$ akan turun pula seiring dengan semakin bertambahnya volume kadar filler dalam campuran. Hubungan Marshall Quotient Lataston HRS - WC gradasi semi senjang diperlihatkan pada Gambar 9.

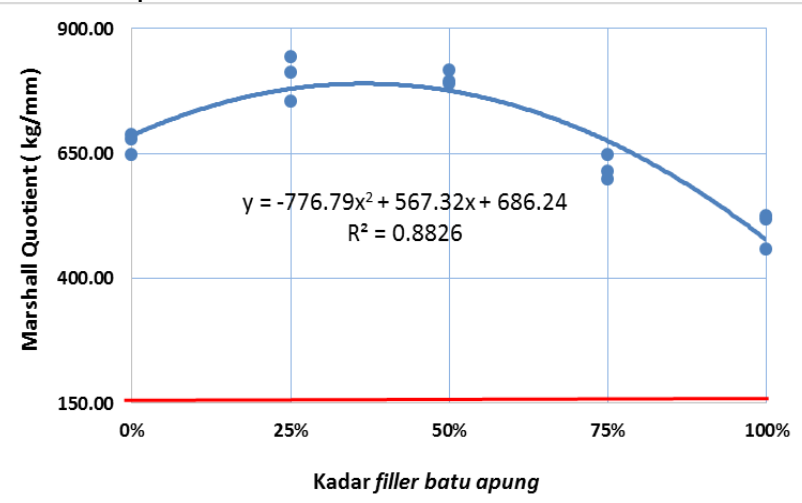

Gambar 9. Grafik hubungan Marshall Quotient (MQ) Lataston HRS-WC gradasi semi senjang

\section{Analisis terhadap VMA (Void in Mineral Agregate)}

Semakin banyak filler batu apung akan membuat rongga dalam butiran agregat yang terisi aspal semakin banyak (VMA). Hal disebabkan karena pada saat penumbukan, aspal lebih banyak mengikat filler batu apung ketimbang mengisi rongga dalam agregat sehingga rongga dalam agregat yang tidak terisi aspal semakin besar. 


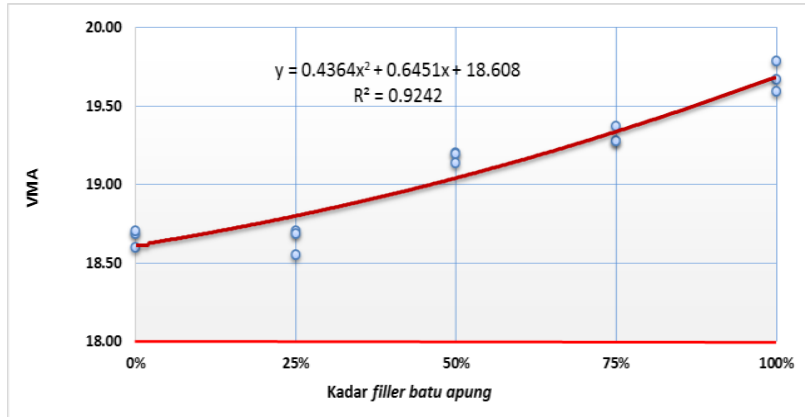

Gambar 10. Grafik hubungan VMA Lataston HRS-WC gradasi senjang

Semakin banyak filler batu apung akan membuat rongga dalam butiran agregat yang terisi aspal semakin banyak (VMA). Hal disebabkan karena pada saat penumbukan, aspal lebih banyak mengikat filler batu apung ketimbang mengisi rongga dalam agregat sehingga rongga dalam agregat yang tidak terisi aspal semakin besar.

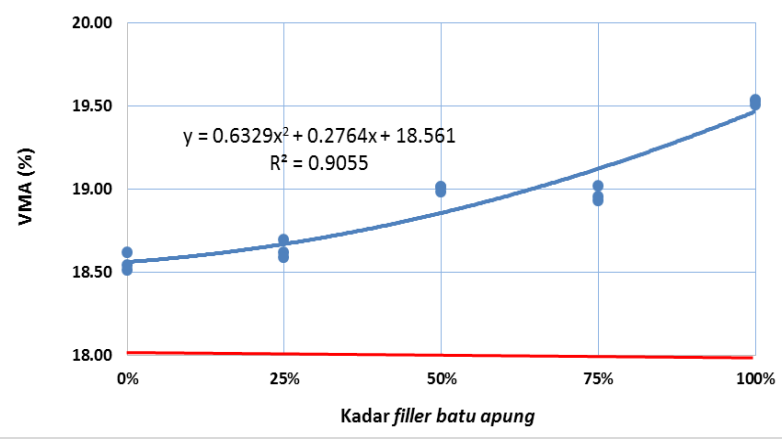

Gambar 11. Grafik Hubungan VMA Lataston HRS-WC Gradasi semi senjang

\section{Analisis terhadap VFB (Void Filled with Bitumen)}

Semakin banyak filler batu apung akan membuat rongga dalam campuran yang terisi aspal semakin sedikit (VFB). Hal disebabkan karena pada saat penumbukan, aspal lebih banyak mengikat filler batu apung dibandingkan mengisi rongga dalam campuran sehingga rongga dalam campuran yang terisi oleh aspal (VFB) semakin kecil.

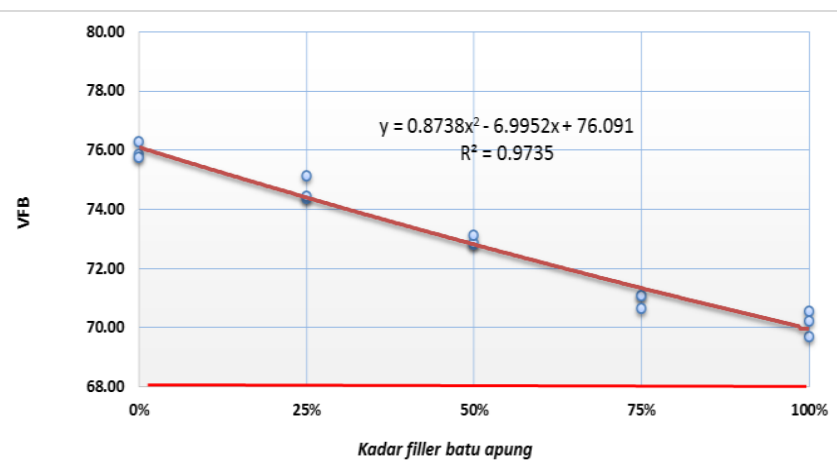

Gambar 12. Grafik hubungan VFB Lataston HRS-WC gradasi senjang
Semakin banyak filler batu apung akan membuat rongga dalam campuran yang terisi aspal semakin sedikit (VFB). Hal disebabkan karena pada saat penumbukan, aspal lebih banyak mengikat filler batu apung dibandingkan mengisi rongga dalam campuran sehingga rongga dalam campuran yang terisi oleh aspal (VFB) semakin kecil.

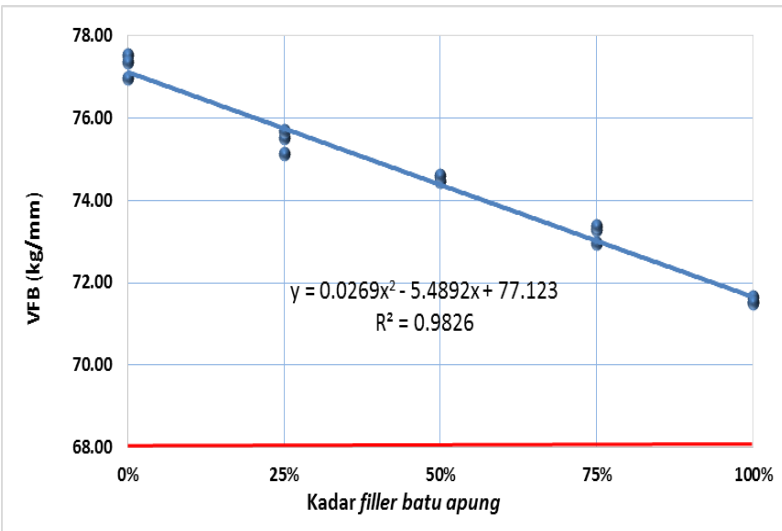

Gambar 13. Grafik hubungan VFB Lataston HRS-WC gradasi semi senjang

\section{Penentuan Kadar Filler Optimum}

Dari hasil pengujian Marshall Immertion diperoleh nilai rata-rata untuk indeks perendaman yaitu 95,73. Nilai indeks perendaman ini telah memenuhi standar yang ditetapkan oleh Bina Marga yaitu $\geq \mathbf{9 0} \%$. Berdasarkan nilai tersebut dapat disimpulkan bahwa perkerasan jalan yang menggunakan batu aung sebagai filler untuk lataston HRS-WC gradasi senjang tahan terhadap suhu dan perendaman dalam air.

Campuran Lataston HRS-WC gradasi senjang

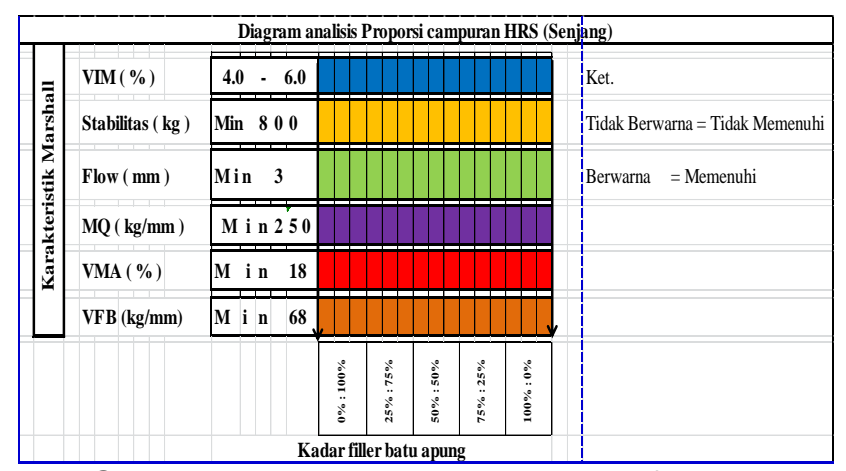

Gambar 14. Diagram analisis kadar filler optimum campuran Lataston HRS-WC senjang 
Tabel 2. Indeks perendaman untuk Lataston HRS-WC senjang

\begin{tabular}{|c|c|c|c|c|}
\hline Benda lji & Kadar Filler $(\%)$ & $\begin{array}{l}\text { Stabilitas Marshall } \\
\text { Immertion (kg) }\end{array}$ & $\begin{array}{l}\text { Stabilitas Marshall } \\
\text { Konvensional } \mid(k g)\end{array}$ & $\begin{array}{c}\text { Indeks perendaman } \\
\mathbb{P} .(\%)\end{array}$ \\
\hline 1 & 100 & 1754.15 & 1830.00 & 95.86 \\
\hline 2 & 100 & 1698.75 & 1775.10 & 95.70 \\
\hline 3 & 100 & 1680.29 & 1756.80 & 95.64 \\
\hline \multicolumn{2}{|c|}{ Rata-rata } & 1711.06 & 1787.3 & 95.73 \\
\hline
\end{tabular}

IP $=\frac{\text { Stabilitas Marshall Immertion }}{\text { Stabilitas Marshall Konvensional }} \times 100 \%$

$=\frac{1711,06}{1787,3} \times 100 \%$

$=95,73 \%$

\section{Campuran Lataston HRS-WC Gradasi Semi Senjang}

Dari hasil pengujian Marshall Immertion diperoleh nilai rata-rata untuk indeks perendaman yaitu 96,66. Nilai indeks perendaman ini telah memenuhi standar yang ditetapkan oleh Bina Marga yaitu $\geq \mathbf{9 0 \%}$. Berdasarkan nilai tersebut dapat disimpulkan bahwa perkerasan jalan yang menggunakan batu apung sebagai filler untuk lataston HRS-WC gradasi semi senjang tahan terhadap suhu dan perendaman dalam air.

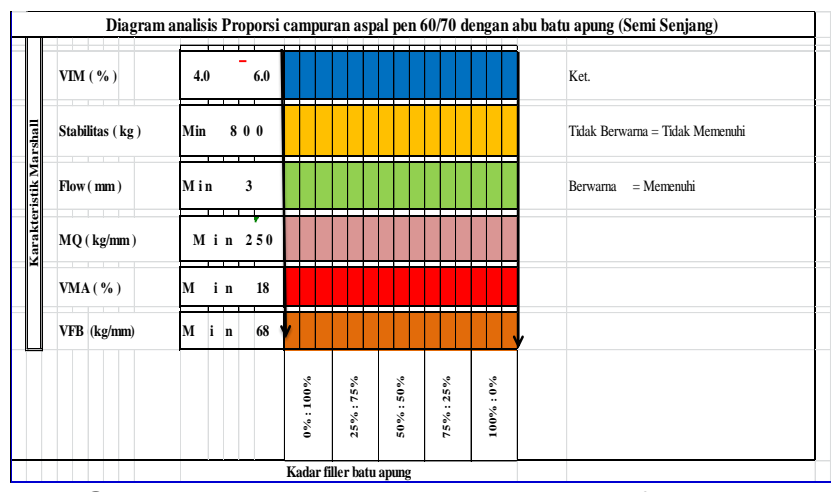

Gambar 15. Diagram analisis kadar filler optimum campuran Lataston HRS-WC semi senjang

Tabel 3. Indeks perendaman untuk Lataston HRS-WC semi senjang

\begin{tabular}{|c|c|c|c|c|}
\hline Benda Uji & Kadar Filler (\%) & $\begin{array}{c}\text { Stabilitas Marshall } \\
\text { Immertion }(\mathrm{kg})\end{array}$ & $\begin{array}{c}\text { Stabilitas Marshall } \\
\text { Konvensional }(\mathrm{kg})\end{array}$ & $\begin{array}{c}\text { Indeks perendaman } \\
\text { IP. }(\%)\end{array}$ \\
\hline 1 & 100 & 2141.91 & 2215.76 & 96.67 \\
\hline 2 & 100 & 2160.37 & 2234.23 & 96.69 \\
\hline 3 & 100 & 2104.98 & 2178.83 & 96.61 \\
\hline \multicolumn{2}{|c|}{ Rata-rata } & 2135.75 & 2209.61 & 96.66 \\
\hline
\end{tabular}

IP $=\frac{\text { Stabilitas Marshall Immertion }}{\text { Stabilitas Marshall Konvensional }} \times 100 \%$

$=\frac{2135,75}{2209,61} \times 100 \%$

$=96,66 \%$

\section{KESIMPULAN}

Komposisi campuran Lataston HRS-WC bergradasi senjang $17,75 \%$ agregat kasar, 68,63\% agregat halus, 6,75\% kadar aspal, dan 6,88\% filler batu apung.Komposisi campuran lataston HRS-WC bergradasi semi senjang 26,25\% agregat kasar, $60,13 \%$ agregat halus, 6,75\% kadar aspal dan $6,88 \%$ filler batu apung. Hasil pengujian Marshall Immertion diperoleh Indeks Perendaman atau Indeks Kekuatan sisa (IKS) 95,73\% untuk Lataston HRSWC Senjang dan 96,66\% untuk Lataston HRS-WC Semi Senjang, yang artinya campuran Lataston HRS-WC tersebut tahan terhadap suhu, lamanya perendaman dan terendam air.

\section{DAFTAR PUSTAKA}

[1] "Spesifikasi Umum Bina Marga Divisi 62010 Perkerasan Aspal." [Online]. Available: https://www.scribd.com/doc/52889551/Spesifikas i-Umum-Bina-Marga-Divisi-6-2010-Perk-ErasAn-Aspal.

[2] "Kinerja Campuran Hot Rolled Sheet-wearing Course (Hrs-wc) Dengan Filler Abu Ampas Tebu Neliti." [Online]. Available: https://www.neliti.com/publications/217437/kinerj a-campuran-hot-rolled-sheet-wearing-coursehrs-wc-dengan-filler-abu-ampas. [Accessed: 09Dec-2019].

[3] "Campuran Hot Rolled Sheet (HRS) dengan Material Piropilit Sebagai Filler yang Tahan Hujan Asam | Ambarwati | Rekayasa Sipil." [Online]. Available: https://rekayasasipil.ub.ac.id/index.php/rs/article/ view/136.

[4] I. Arifiardi, W. Hadi, and A. Purnomo, "Pengaruh Penggunaan Pasir Pantai Carita Sebagai Campuran Agregat Halus Pada Lapis Permukaan Aspal Beton Terhadap Persyaratan Parameter Marshall," p. 16, 2016.

[5] "Studi Penggunaan Serbuk Bata Merah Sebagai Filler Pada Perkerasan HRS WC." [Online]. Available: https://adoc.tips/queue/studipenggunaan-serbuk-bata-merah-sebagai-fillerpada-perke.html.

[6] "Pengaruh Kadar Zeolite Sebagai Filler Terhadap Campuran Aspal Beton." [Online]. Available: http://e-journal.uajy.ac.id/3675/.

[7] A. S. Amal, "Pemanfaatan Abu Bagasse Sebagai Filler Terhadap Nilai Marshall Test Pada Campuran Asphalt Treated Base ( ATB )," JMTS, vol. 9, no. 2, Jan. 2013. 